\title{
Antimicrobial activity of novel Lactococcus lactis strains against Salmonella Typhimurium DT12, Escherichia coli 0157:H7 VT- and Klebsiella pneumoniae in raw and pasteurised camel milk
}

Bragason, Esben; Berhe, Tesfemariam; Dashe, Dakalo; Sørensen, Kim Ib; Guya, Mituku E.; Hansen, Egon Bech

Published in:

International Dairy Journal

Link to article, DOI:

10.1016/j.idairyj.2020.104832

Publication date:

2020

Document Version

Peer reviewed version

Link back to DTU Orbit

Citation (APA):

Bragason, E., Berhe, T., Dashe, D., Sørensen, K. I., Guya, M. E., \& Hansen, E. B. (2020). Antimicrobial activity of novel Lactococcus lactis strains against Salmonella Typhimurium DT12, Escherichia coli O157:H7 VT and Klebsiella pneumoniae in raw and pasteurised camel milk. International Dairy Journal, 111, [104832].

https://doi.org/10.1016/j.idairyj.2020.104832

\section{General rights}

Copyright and moral rights for the publications made accessible in the public portal are retained by the authors and/or other copyright owners and it is a condition of accessing publications that users recognise and abide by the legal requirements associated with these rights.

- Users may download and print one copy of any publication from the public portal for the purpose of private study or research.

- You may not further distribute the material or use it for any profit-making activity or commercial gain

- You may freely distribute the URL identifying the publication in the public portal 
2 Antimicrobial Activity of Novel Lactococcus Lactis Strains against Salmonella Typhimurium

3 DT12, Escherichia Coli O157:H7 VT- and Klebsiella pneumoniae in Raw and Pasteurized

4 Camel Milk

5

6 Esben Bragason ${ }^{\mathrm{a}}$, Tesfemariam Berhe ${ }^{\mathrm{b}}$, DakaloDashe $^{\mathrm{b}}$, Kim Ib Sørensen $^{\mathrm{c}}$, Mituku E. Guya $^{\mathrm{b}}$, 7 Egon Bech Hansen ${ }^{\mathrm{a}}$

8

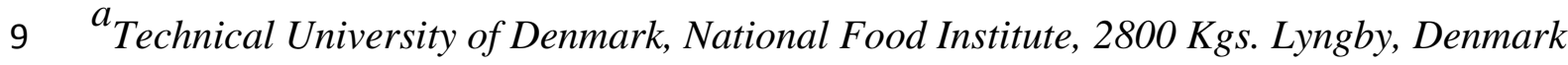

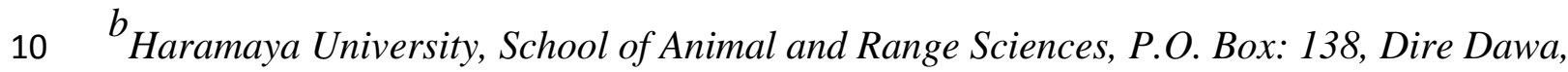

11 Ethiopia

$12{ }^{C}$ Chr. Hansen A/S, Bøge Alle 10-12, 2970 Hørsholm, Denmark

13

14 Corresponding author:

15 Egon Bech Hansen

16 DTU Food, Technical University of Denmark

17 Kemitorvet, Building 202

18 DK-2800 Kgs. Lyngby, Denmark

19 Phone: +4535886203

20 E-mail: egbh@ food.dtu.dk 


\section{Abstract}

22 The present study investigated inhibition of multiple food related pathogens in raw and 23 pasteurised camel milk during fermentation with four novel Lactococcus lactis strains. All 24 pathogens alone in camel milk reached $8.0 \log \left(\mathrm{CFU} \mathrm{mL} \mathrm{m}^{-1}\right)$. When the pathogens were cultivated with L. lactis MS22333 or MS22337 they were reduced between 0.9-6.0 $\log (\mathrm{CFU}$ $\left.\mathrm{mL}^{-1}\right)$. L. lactis MS22314 and MS22336 showed no antimicrobial activity.

Bad hygiene and lack of cooling facilities have resulted in spontaneously fermented African camel milk with high incidence of contaminants. Starter cultures promote food safety by controlling the fermentation. Commercial cultures developed for bovine milk acidify poorly in camel milk and cultures optimized for camel milk with inhibitory effects against pathogens are therefore needed.

To our knowledge, we have for the first time demonstrated that some L. lactis strains isolated from camel milk can inhibit the growth of food related pathogens in both raw and pasteurised camel milk.

\section{Introduction}

37 The quality and safety of milk is highly influenced by the rate of contamination by pathogens. Staphylococcus spp., Escherichia coli, Salmonella spp., Klebsiella spp., Campylobacter jejuni, Bacillus cereus and Listeria monocytogenes have been reported multiple times with high frequency of contamination in milk (Ismaili, Saidi, Zahar, Hamama, \& Ezzaier, 2019;

41 Oliver, Jayarao, \& Almeida, 2005; Tetili, Bendali, Perrier, \& Sadoun, 2017). from camel milk. Samples were collected in Ethiopian Somali region where poor water 
44 quality, bad sanitation, uncooled preservation and transportation traditions were some of the main factors promoting contamination(Abera et al., 2016).

Food poisoning is relatively harmless in developed countries where a medical system can support fast recovery and hydration. In African undeveloped countries, diarrhoea, salmonellosis, dehydration and vomiting can be fatal. In Africa food poisoning is estimated to kill 137.000 persons yearly (Bisholo, Ghuman, \& Haffejee, 2018; Rebgui et al., 2013). Camelus dromedarius is an important milk producer in sub-Saharan and East African countries, where raw and non-heat-treated dairy products are consumed. Camel milk is mainly consumed directly after milking or as sour milk, often due to spontaneous fermentation (Abera et al., 2016).

The acidification of camel milk is a complicated procedure due to relative higher concentrations of antibacterial and antiviral substances compared to bovine milk (El Agamy, Ruppanner, Ismail, Champagne, \& Assaf, 1992). Commercial starter cultures designed for bovine milk have been tested in camel milk and they were able to acidify camel milk to comparable final $\mathrm{pH}$ but with slower acidification rates (Berhe et al., 2018). Starter cultures designed specific for camel milk with optimum acidification rates to both increase the food quality and inhibit growth of spoilage and pathogenic microorganisms remains to be

61 developed.

Lactococcus lactis are used in many starter cultures to ferment foods and thereby prevent growth of pathogens or spoilage bacteria by producing multiple antimicrobial substances (Cizeikiene, Juodeikiene, Paskevicius, \& Bartkiene, 2013; Jay, 1982; Kondrotiene et al., 2018; Mufandaedza, Viljoen, Feresu, \& Gadaga, 2006; Roessland, Borge, Langsrud, \& Sørhaug, 2003). 
67 Studies of inhibition of several common food pathogens by L. lactis strains have been

68

69

70

71

72

73

74

75

76

77

78

79

80

81

82 reported in cow milk and cheese products (Kasra-Kermanshahi \& Mobarak-Qamsari, 2015; Kondrotiene et al., 2018; Roessland et al., 2003; Tetili et al., 2017). To our knowledge, only few studies have described inhibition of food pathogens using lactic acid bacteria (LAB) isolated from camel milk (Benmechernene et al., 2013; Rahmeh et al., 2019). Rahmeh et al. (2019) characterised antimicrobial activity of multiple genera within lactic acid bacteria and the distribution of LAB in raw camel milk from western Asia. Benmechernene et al. (2013) have shown that two strains of Leuconostoc mesenteroides subsp. mesenteroides isolated from Algerian camel milk could be used as a bioactive strain against $L$. monocytogenes and $S$. aureus.

The aim of this study was to identify potential L. lactis candidates for a starter culture with antimicrobial properties demonstrated in camel milk to enhance food safety in African countries.

\section{Materials and methods}

\subsection{Bacterial strains}

L. lactis strains were obtained from the strain collection at the National Food Institute at the Technical University of Denmark. Originally, the strains MS22314, MS22333, MS22336 and MS22337 were isolated from spontaneous fermented camel milk in Ethiopia (Fugl et al., 2017). Genome sequences of the strains can be accessed at the Genbank under BioSample numbers: SAMN13701540, SAMN13701541, 76 SAMN13701542, SAMN13701543

(Bragason, Svendsen, Guya, Berhe, \& Hansen, 2020). The cultures were grown for $24 \mathrm{~h}$ at 30 ${ }^{\circ} \mathrm{C}$ in M17 broth (Oxoid, Thermo Scientific, Hampshire, UK) containing 0.5\% lactose.

Klebsiella pneumoniae (MS22380) was obtained from DSMZ - German Collection of Microorganisms and Cell Cultures (DSM 30104). 
91 Salmonella Typhimurium DT12 (MS20842) and E. coli O:157 VT- (MS21811) were obtained

92 from the strain collection at the National Reference Laboratory for Salmonella and zoonotic

93 Escherichia coli at the Technical University of Denmark. S. Typhimurium DT12 was

94 originally isolated in cow faeces. All pathogens were grown for $24 \mathrm{~h}$ at $37^{\circ} \mathrm{C}$ in brain-heart

95 infusion (BHI) broth (Oxoid, Thermo Scientific, Hampshire, UK).

96

97

98

99

100

101

102

103

104

105

106

107

108

109

110

111

112

113

\subsection{Media Preparation}

Unpasteurized camel milk provided by Kamelenmelkerij Smits (Berlicum, Netherlands) was sent within $24 \mathrm{~h}$ after bottled on $0.5 \mathrm{~L}$ plastic bottles and immediately stored at $-40{ }^{\circ} \mathrm{C}$ until use. The milk was placed in the fridge 2 days before use at $5{ }^{\circ} \mathrm{C}$ to thaw. Enzymatic inactivation of the milk was carried out by heating the milk for 10 minutes at $96{ }^{\circ} \mathrm{C}$ in a VWR water bath (Grant Instruments Ltd., Cambridge, UK) followed by cooling to room temperature before further use.

Raw bovine milk was obtained from a farmer on Zealand (Denmark) and stored in the fridge at $5^{\circ} \mathrm{C}$ until use.

Preparation of Prussian blue (PB) agar plates were made following the formulation described by Saito, Seki, Iida, Nakayama, \& Yoshida (2007). M17-lac agar were made using M17 agar provided by SSI Diagnostica (Hilleroed, Denmark) in $200 \mathrm{~mL}$ bottles and sterile $10 \%$ lactose solution were added to a final concentration of 0,5\%. Xylose-Lysine-Desoxycholate (XLD) agar plates were made following the directions by the manufacturer (Oxoid, Thermo Scientific, Hampshire, UK). MacConkey no. 3 agar plates were provided by SSI Diagnostica (Hilleroed, Denmark) ready to use. All agar plates kept at $5{ }^{\circ} \mathrm{C}$ until use.

\subsection{Antimicrobial activity of $L$. lactis}


114 Aliquots of $50 \mathrm{~mL}$ raw or pasteurised camel milk were stored in $50 \mathrm{~mL}$ falcon tubes. Milk samples were inoculated with overnight cultures of each pathogen $(5 \mu \mathrm{L})$ L. lactis strain $(50$ $\mu \mathrm{L})$. Falcon tubes were homogenized using a Vortex mixer and incubated at $30{ }^{\circ} \mathrm{C}$ for $75 \mathrm{~h}$.

117 Sampling were withdrawn every 10-20 h over a period of three days.

\subsection{Viable Bacteria Count}

At each sampling interval the milk was homogenized and $100 \mu \mathrm{L}$ were removed for serial dilutions. Maximum Recovery Diluent provided by SSI Diagnostica (Hilleroed, Denmark) were used to dilute samples. Adequate dilutions were chosen and $40 \mu \mathrm{L}$ was pipetted on a half agar plate. M17-lac agar plates were incubated for $48 \mathrm{~h}$ at $30{ }^{\circ} \mathrm{C}$ and used for L. lactis strains, XLD agar plates incubated for $24 \mathrm{~h}$ at $37^{\circ} \mathrm{C}$ and used for $S$. Typhimurium DT12 and MacConkey No.3 incubated for $24 \mathrm{~h}$ at $37^{\circ} \mathrm{C}$ and used for K. pneumoniae and E. coli O:157

$\mathrm{VT}^{-}$. Colonies were counted using a Stuart SC6+ Colony Counter (Cole-Parmer,

Staffordshire, UK) and colony-forming units (CFU) per millilitre were calculated using a weighted mean.

\subsection{Measurement of Hydrogen Peroxide}

Determination of $\mathrm{H}_{2} \mathrm{O}_{2}$ concentration in samples was carried out using CDR FOODLAB ${ }^{\circledR}$ (CDR s.r.l, Florence, Italy) photometric analyser according to manufacturer's instructions. Samples were taken from an overnight culture containing either MS22333 or MS22337. The L. lactis strains was grown in both bovine milk and camel milk for evaluation of possible differences.

\section{Results}

In this study L. lactis strains were inoculated into both raw and pasteurised camel milk at around $10^{6}-10^{7} \mathrm{CFU} \mathrm{mL} \mathrm{m}^{-1}$ to simulate the fermentation. Results are presented in Figure 1 and 
137 2. All L. lactis strains reached levels of $10^{8}-10^{9} \mathrm{CFU} \mathrm{mL} \mathrm{m}^{-1}$ both in raw and pasteurised milk

138

139

140

141

142 with $\mathrm{pH}$ ranging between 4.0 - 4.5.

\subsection{Inhibition of $E$. coli O:157 VT- in raw camel milk}

The inhibitory effect varied between L. lactis strains MS22314, MS22333, MS22336 and MS22337. The inhibition is shown in Figure 1. The pathogenic E coli O:157 VT- was inoculated at about $4.7 \cdot 10^{4}-5.0 \cdot 10^{5} \mathrm{CFU} \mathrm{mL}^{-1}$ and after $8 \mathrm{~h}$ inhibition effects were detected. MS22333 and MS22337 decreased the concentration of $E$ coli $\mathrm{O}: 157 \mathrm{VT}^{-}$with $0.9-4.8$ $\log \left(\mathrm{CFU} \mathrm{mL}^{-1}\right)$ within $54 \mathrm{~h}$ at $30^{\circ} \mathrm{C}$. In contrast did MS22314 and MS22336 did not inhibit the growth of $E$ coli $\mathrm{O}: 157 \mathrm{VT}^{-}$at any stages of fermentation. After $8 \mathrm{~h}$ of incubation the concentration of $E$ coli $\mathrm{O}: 157 \mathrm{VT}^{-}$was $0.5-1.0 \log \left(\mathrm{CFU} \mathrm{mL} \mathrm{m}^{-1}\right)$ higher in milk samples containing either MS22314 or MS22333 compared to $E$ coli O:157 VT- growing alone in raw camel milk. After $54 \mathrm{~h}$, all three samples reached a stable $E$ coli $\mathrm{O}: 157 \mathrm{VT}^{-}$concentration of $5.5-7.5 \cdot 10^{7} \mathrm{CFU} \mathrm{mL}{ }^{-1}$

In the absence of L. lactis strains and E. coli O:157 $\mathrm{VT}^{-}$the raw camel milk sample showed both growth on M17-lac and MacConkey no. 3 agar plates indicating both natural LAB and unknown Enterobacteriaceae.

\subsection{Inhibition of Salmonella Typhimurium DT12 and Klebsiella pneumoniae in}

\section{pasteurised camel milk}

The effect of L. lactis MS22333 and MS22337 to inhibit the pathogens in pasteurised camel milk is presented in Figure 2B and Figure 2C. Both $S$. Typhimurium DT12 and $K$. pneumoniae were inoculated at concentrations about $6.0 \log \left(\mathrm{CFU} \mathrm{mL} \mathrm{L}^{-1}\right)$, while L. lactis strains were about 7.0-7.5 $\log \left(\mathrm{CFU} \mathrm{mL}^{-1}\right)$. Overall L. lactis MS22333 and MS22337 inhibited both pathogens and a mixed starter culture composed of both did not show a significant difference. No inhibitory effect on $S$. Typhimurium DT12 were seen the first $21 \mathrm{~h}$ of the 
fermentation. After $47 \mathrm{~h}$, it was impossible to detect $S$. Typhimurium DT12 in milk samples containing either MS22333 or MS22337 or a 50:50 mixed culture.

Similar results were seen with K. pneumoniae at $21 \mathrm{~h}$. At $47 \mathrm{~h}$ no growth on MacConkey no. 3 agar were detected in the $L$. lactis MS22337 inoculated milk. The mixed L. lactis culture and L. lactis MS22333 showed concentrations of respectively 4.5 and $3.8 \log \left(\mathrm{CFU} \mathrm{mL} \mathrm{mL}^{-1}\right)$ at same sampling interval. After $75 \mathrm{~h}, K$. pneumoniae were impossible to detect in all milk samples inoculated with a L. lactis strain.

\subsection{Production of hydrogen peroxide}

Characterisation of $\mathrm{H}_{2} \mathrm{O}_{2}$ producing L. lactis strains were carried out using PB agar. Prussian blue colour formation was seen as a blue halo around positive colonies. MS22333 showed strong blue colour formation around each colony, while MS22337 had small light blue halos around most colonies (data not shown). L. lactis MG1363 were included as a negative control. L. lactis MS22314 and MS2236 looked like L. lactis MG1363 with no clear colour formation.

Quantification of $\mathrm{H}_{2} \mathrm{O}_{2}$ levels in camel milk is shown in Table 1. Overall, none of the L. lactis strains showed high concentrations of $\mathrm{H}_{2} \mathrm{O}_{2}<24 \mathrm{ppm}$. The concentration of $\mathrm{H}_{2} \mathrm{O}_{2}$ in both raw and pasteurised camel milk were at the beginning below detection level (DL) $<1.5 \mathrm{ppm}$. Similar results were obtained for bovine milk. After $24 \mathrm{~h}$ at $30^{\circ} \mathrm{C}$, all samples showed an increased $\mathrm{H}_{2} \mathrm{O}_{2}$ concentration. 23.8 ppm were the highest concentration detected, which was in pasteurised camel milk inoculated with L. lactis MS22337.

\section{Discussion}


Milk and processed dairy products are consumed globally by all social classes. Contaminants can occur through the food chain from milking of the animal to the final consumers. Bacterial contamination of milk should be minimal, as contaminated milk is a threat to public health. As the majority of camel milk producers lack cooling facilities, the camel milk often acidifies by spontaneous fermentation (Holzapfel, 2002). We have been studying LAB in spontaneous fermented camel milk to isolate the most beneficial strains based on antimicrobial activity and rate of fermentation. Our findings of two strains inhibiting E. coli O:157 $\mathrm{VT}^{-}$in raw camel milk, demonstrates antimicrobial activity of L. lactis strains with comparable acidification rates and $\mathrm{pH}$ levels as commercial starter cultures (Berhe et al., 2018). A study by Charlier et al. (2008) demonstrated that low-acidifying L. lactis strains efficiently could inhibit the growth of $S$. aureus in milk. The inhibitory effect seen in L. lactis MS22333 and MS22337 and not in MS22314 and MS22336 is thereby not due to lactic acid production as they all had similar acidification curves (data not shown) and similar $\mathrm{pH}$ levels. Same strains showed $\mathrm{H}_{2} \mathrm{O}_{2}$ production on PB agar, but only low levels $<24$ ppm could be detected using aerated (Ito et al., 2003). The results shown in Table 1 could be residue levels, from an incomplete utilisation of hydrogen peroxide potential caused by anaerobic conditions. Furthermore, $\mathrm{H}_{2} \mathrm{O}_{2}$ is known to have a short lifetime in milk, and in raw milk, $\mathrm{H}_{2} \mathrm{O}_{2}$ may activate the naturally occurring lactoperoxidase (LP) enzyme system (Martin et al., 2014). Detection of $\mathrm{H}_{2} \mathrm{O}_{2}$ in a complex media such as milk can be a challenge. $\mathrm{H}_{2} \mathrm{O}_{2}$ concentrations as low as $60 \mathrm{mg} \mathrm{L}^{-1}$ administered along with $28 \mathrm{mg} \mathrm{L}^{-1}$ thiocyanate have been reported to activate the LP system and extend the shelf life of raw ovine, bovine and caprine milk for several days (Boulares, Mankai, \& Hassouna, 2011). 
To our knowledge, inhibition of pathogens in pasteurised camel milk have not been demonstrated before. L. lactis MS22333 and MS22337 showed complete inhibition of both $S$. Typhimurium DT12 and K. pneumoniae within 75 h shown in Figure 2B and 2C. The reason for the $4.07 \log \left(\mathrm{CFU} \mathrm{mL} \mathrm{m}^{-1}\right)$ decrease of $K$. pneumoniae in fermented camel milk is unknown, but may be due to growth of unknown bacteria inhibiting and utilizing lactose, which was seen as growth on M17-lac agar plates reaching $6.0 \log \left(\mathrm{CFU} \mathrm{mL} \mathrm{mL}^{-1}\right)$ at $47 \mathrm{~h}$ (Figure 2A).

Pasteurisation of camel milk inactivates the LP system (Sharma \& Rajput, 2014). The inhibition of $S$. Typhimurium DT12 and K. pneumoniae by L. lactis MS22333 and MS22337, indicates that other antimicrobial mechanisms are happening during fermentation. According to literature, L. lactis have shown to inhibit pathogens by producing bacteriocins and other low molecular compounds (Armas, Camperio, \& Marianelli, 2017; Cardinal, Meghrous, Lacroix, \& Simard, 1997; Enan, Abdel-Shafi, Ouda, \& Negm, 2013; Loh, Lim, \& Ting, 2017; Millette, Smoragiewicz, \& Lacroix, 2004).

We have previously published the genome sequences of L. lactis MS22314, MS22333, MS22336 and MS22337 (Bragason et al., 2020), where annotation of the contigs showed that MS22333 were the only strain without any genes coding for antibiotic resistance. Starter cultures containing resistance genes can possibly be a critical source of spreading antibiotic resistance, and studies have found multiple starter cultures with resistance genes (Kastner et al., 2006; Katla, Kruse, Johnsen, \& Herikstad, 2001). Future studies should explore the mechanism of inhibition and develop L. lactis MS22333 into a starter culture specific for camel dairy.

\section{Conclusions}

Our present study shows that L. lactis MS22333 and L. lactis MS22337 isolated from spontaneous fermented camel milk have antimicrobial abilities and can be applied as a starter 
culture to promote food safety in African countries. We have demonstrated for the first time that $S$. Typhimurium and $K$. pneumoniae can be eliminated in pasteurised camel milk by $L$. lactis strains. Further work has to be done to explain the mechanism of inhibition.

\section{Acknowledgements}

This study was partly performed from February to June 2018 and August to December 2019 as a part of the project "Haramaya Camel Dairy", a collaboration between Haramaya University, Chr. Hansen A/S, Copenhagen University, and the Technical University of Denmark. The study is funded by the Danish Development Fund, Danida, through grant DFC 12-017DTU. Thanks to Bodil Madsen for technical and professional assistance in the laboratory at the Technical University of Denmark.

\section{References}

Abera, T., Legesse, Y., Mummed, B., \& Urga, B. (2016). Bacteriological quality of raw camel milk along the market value chain in Fafen zone, Ethiopian Somali regional state. BMC Research Notes, 9(1), 16-21. https://doi.org/10.1186/s13104-016-2088-1

Armas, F., Camperio, C., \& Marianelli, C. (2017). In Vitro Assessment of the Probiotic Potential of Lactococcus lactis LMG 7930 against Ruminant Mastitis-Causing Pathogens. PLOS ONE, 12(1), 1-13. https://doi.org/10.1371/journal.pone.0169543

Benmechernene, Z., Chentouf, H. F., Yahia, B., Fatima, G., Quintela-Baluja, M., Calo-Mata, P., \& Barros-Velázquez, J. (2013). Technological Aptitude and Applications of Leuconostoc mesenteroides Bioactive Strains Isolated from Algerian Raw Camel Milk. BioMed Research International, 2013. https://doi.org/10.1155/2013/418132 
Comparison of the acidification activities of commercial starter cultures in camel and bovine milk. LWT - Food Science and Technology, 89(October 2017), 123-127. https://doi.org/10.1016/j.lwt.2017.10.041

Bisholo, K. Z., Ghuman, S., \& Haffejee, F. (2018). Food-borne disease prevalence in rural villages in the Eastern Cape, South Africa. African Journal of Primary Health Care \& Family Medicine, 10(1), 1-5. https://doi.org/10.4102/phcfm.v10i1.1796

Boulares, M., Mankai, M., \& Hassouna, M. (2011). Effect of thiocyanate and hydrogen peroxide on the keeping quality of ovine, bovine and caprine raw milk. International Journal of Dairy Technology, 64(1), 52-56. https://doi.org/10.1111/j.14710307.2010.00644.x

Bragason, E., Svendsen, C. A., Guya, M. E., Berhe, T., \& Hansen, E. B. (2020). Draft Genome Sequences of Lactococcus lactis strains MS22314, MS22333, MS22336, and MS22337, Isolated from Fermented Camel Milk in Ethiopia. Microbiology Resource Announcements, Submitted.

Cardinal, M. J., Meghrous, J., Lacroix, C., \& Simard, R. E. (1997). Isolation of Lactococcus lactis strains producing inhibitory activity against Listeria. Food Biotechnology, 11(2), 129-146. https://doi.org/10.1080/08905439709549928

Charlier, C., Even, S., Gautier, M., \& Le Loir, Y. (2008). Acidification is not involved in the early inhibition of Staphylococcus aureus growth by Lactococcus lactis in milk. International Dairy Journal, 18(2), 197-203. https://doi.org/10.1016/j.idairyj.2007.03.015

Cizeikiene, D., Juodeikiene, G., Paskevicius, A., \& Bartkiene, E. (2013). Antimicrobial activity of lactic acid bacteria against pathogenic and spoilage microorganism isolated from food and their control in wheat bread. Food Control, 31(2), 539-545. 
El Agamy, E. I., Ruppanner, R., Ismail, A., Champagne, C. P., \& Assaf, R. (1992).

Enan, G., Abdel-Shafi, S., Ouda, S., \& Negm, S. (2013). Novel antibacterial activity of

Fugl, A., Berhe, T., Kiran, A., Hussain, S., Laursen, M. F., Bahl, M. I., ... Hansen, E. B. (2017). Characterisation of lactic acid bacteria in spontaneously fermented camel milk and selection of strains for fermentation of camel milk. International Dairy Journal, 73, 19-24. https://doi.org/10.1016/j.idairyj.2017.04.007

Holzapfel, W. H. (2002). Appropriate starter culture technologies for small-scale fermentation in developing countries. International Journal of Food Microbiology, 75(3), 197-212. https://doi.org/10.1016/S0168-1605(01)00707-3

Ismaili, M. A., Saidi, B., Zahar, M., Hamama, A., \& Ezzaier, R. (2019). Composition and microbial quality of raw camel milk produced in Morocco. Journal of the Saudi Society of Agricultural Sciences, 18(1), 17-21. https://doi.org/10.1016/j.jssas.2016.12.001

Ito, A., Sato, Y., Kudo, S., Sato, S., Nakajima, H., \& Toba, T. (2003). The screening of hydrogen peroxide-producing lactic acid bacteria and their application to inactivating psychrotrophic food-borne pathogens. Current Microbiology, 47(3), 231-236. https://doi.org/10.1007/s00284-002-3993-1

Jay, J. M. (1982). Antimicrobial Properties of Diacetyl. Applied and Environmental Microbiology, 44(3), 525-532. 
Kasra-Kermanshahi, R., \& Mobarak-Qamsari, E. (2015). Inhibition Effect of Lactic Acid Bacteria against Food Born Pathogen, Listeria monocytogenes. Applied Food Biotechnology, 2(4), 11-19.

Kastner, S., Perreten, V., Bleuler, H., Hugenschmidt, G., Lacroix, C., \& Meile, L. (2006). Antibiotic susceptibility patterns and resistance genes of starter cultures and probiotic bacteria used in food. Systematic and Applied Microbiology, 29(2), 145-155. https://doi.org/10.1016/j.syapm.2005.07.009

Katla, A. K., Kruse, H., Johnsen, G., \& Herikstad, H. (2001). Antimicrobial susceptibility of starter culture bacteria used in Norwegian dairy products. International Journal of Food Microbiology, 67(1-2), 147-152. https://doi.org/10.1016/S0168-1605(00)00522-5

Kondrotiene, K., Kasnauskyte, N., Serniene, L., Gölz, G., Alter, T., Kaskoniene, V., ... Malakauskas, M. (2018). Characterization and application of newly isolated nisin producing Lactococcus lactis strains for control of Listeria monocytogenes growth in fresh cheese. LWT - Food Science and Technology, 87, 507-514. https://doi.org/10.1016/j.lwt.2017.09.021

Loh, J. Y., Lim, Y. Y., \& Ting, A. S. Y. (2017). Bacteriocin-like substances produced by Lactococcus lactis subsp. lactis CF4MRS isolated from fish intestine: Antimicrobial activities and inhibitory properties. International Food Research Journal, 24(1), 394400.

Martin, N. H., Friedlander, A., Mok, A., Kent, D., Wiedmann, M., \& Boor, K. J. (2014). Peroxide Test Strips Detect Added Hydrogen Peroxide in Raw Milk at Levels Affecting Bacterial Load. Journal of Food Protection, 77(10), 1809-1813. https://doi.org/10.4315/0362-028X.JFP-14-074

Millette, M., Smoragiewicz, W., \& Lacroix, M. (2004). Antimicrobial potential of 

immobilized Lactococcus lactis subsp. lactis ATCC 11454 against selected bacteria. Journal of Food Protection, 67(6), 1184-1189. https://doi.org/10.4315/0362-028X67.6.1184

Mufandaedza, J., Viljoen, B. C., Feresu, S. B., \& Gadaga, T. H. (2006). Antimicrobial properties of lactic acid bacteria and yeast-LAB cultures isolated from traditional fermented milk against pathogenic Escherichia coli and Salmonella enteritidis strains. International Journal of Food Microbiology, 108(1), 147-152. https://doi.org/10.1016/j.ijfoodmicro.2005.11.005

Oliver, S. P., Jayarao, B. M., \& Almeida, R. A. (2005). Review - Foodborne Pathogens in Milk and the Dairy Farm Environment: Food Safety and Public Health Implications. Foodborne Pathogens and Disease, 2(2), 115-137.

Rahmeh, R., Akbar, A., Kishk, M., Al-Onaizi, T., Al-Azmi, A., Al-Shatti, A., ... Akbar, B. (2019). Distribution and antimicrobial activity of lactic acid bacteria from raw camel milk. New Microbes and New Infections, 30. https://doi.org/10.1016/j.nmni.2019.100560

Rebgui, H., Nekkal, N., Benlarabi, S., Hattimy, F. El, Hadrya, F., Soulaymani, A., ... Mokhtari, A. (2013). Food poisoning in Morocco: Evolution and Risk factors. International Journal of Scientific \& Engineering Research, 4(11), 1015-1021.

Roessland, E., Borge, G. I. A., Langsrud, T., \& Sørhaug, T. (2003). Inhibition of Bacillus cereus by strains of Lactobacillus and Lactococcus in milk. International Journal of Food Microbiology, 89(2-3), 205-212. https://doi.org/10.1016/S0168-1605(03)00149-1

Saito, M., Seki, M., Iida, K., Nakayama, H., \& Yoshida, S. (2007). A Novel Agar Medium to Detect Hydrogen Peroxide-Producing Bacteria Based on the Prussian Blue-Forming Reaction. Microbiol. Immunol., 51(9), 889-892. 
349 Sharma, R., \& Rajput, Y. S. (2014). Rapid methods for assessing efficiency of heat treatment $350 \quad$ of milk. Journal of Food Science and Technology, 51(7), 1416-1420.

$351 \quad$ https://doi.org/10.1007/s13197-012-0635-x

352 Tetili, F., Bendali, F., Perrier, J., \& Sadoun, D. (2017). Anti-staphylococcal

353 enterotoxinogenesis of Lactococcus lactis in Algerian raw milk cheese. Food Technology and Biotechnology, 55(4), 511-518.

355 https://doi.org/10.17113/ftb.55.04.17.5105

356 
B\&W:

Figure 1. Evolution of novel L. lactis strains and Gram-negative bacteria in raw camel milk.

Figure 1A. Growth curves of lactose fermenting strains on M17 agar with $0.5 \%$ lactose from raw camel milk fermentations at $30^{\circ} \mathrm{C}$ with Lactococcus lactis strains inoculated. L. lactis

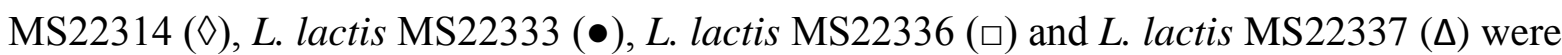

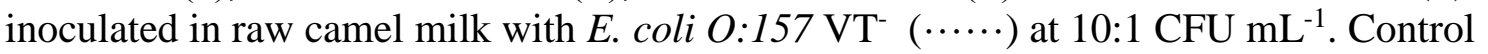
samples without inoculation of L. lactis strains in raw camel milk $(-\times-)$ or with E. coli $O: 157 \mathrm{VT}^{-}(\cdots \circ \cdots)$ inoculated.

Figure 1B. Growth curves of Gram-negative strains on MacConkey agar no. 3 from raw camel milk fermentations at $30^{\circ} \mathrm{C}$ with Lactococcus lactis strains inoculated. L. lactis

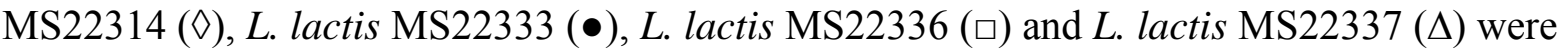
inoculated in raw camel milk with $E$. coli $O: 157 \mathrm{VT}^{-}(\cdots \cdots)$ at $10: 1 \mathrm{CFU} \mathrm{mL}^{-1}$. Control samples without inoculation of $L$. lactis strains in raw camel milk $(-\times-)$ or with $E$. coli $O: 157 \mathrm{VT}^{-}(\cdots \circ \cdots)$ inoculated.

Figure 2. Evolution of novel L. lactis strains and pathogenic bacteria in pasteurised camel milk.

Figure 2A. Growth curves of Lactococcus lactis strains in pasteurised camel milk with Salmonella Typhimurium DT12 or Klebsiella pneumoniae present. L. lactis MS22333 ( $\square$ ), L. lactis MS22337 ( $\Delta)$, a mixed culture of L. lactis MS22333 and L. lactis MS22337( $\diamond)$ were inoculated with either $S$. Typhimurium DT12 (- - ) or K. pneumonieae $(\cdots \cdots)$ at 10:1 CFU $\mathrm{mL}^{-1}$. Control samples without inoculation of L. lactis strains in past. camel milk $(-\mathrm{X}-)$ inoculated with either $S$. Typhimurium DT12 (- - - -) or K. pneumoniae $(\cdots \circ \cdots)$.

Figure 2B. Growth curves of Salmonella Typhimurium DT12 on XLD agar from pasteurised camel milk fermentations at $30^{\circ} \mathrm{C}$ with Lactococcus lactis strains inoculated. L. lactis MS22333 ( $\square)$, L. lactis MS22337 ( $\Delta$ ) and a mixed culture of L. lactis MS22333 and L. lactis MS22337 $(\diamond)$ were inoculated with $S$. Typhimurium DT12 (- - ) at 10:1 CFU mL ${ }^{-1}$. Control samples without inoculation of $L$. lactis strains in past. camel milk $(-\times-)$ inoculated with $S$. Typhimurium DT12 (- - - -).

Figure 2C. Growth curves of Klebsiella pneumoniae on MacConkey agar no. 3 from pasteurised camel milk fermentations at $30^{\circ} \mathrm{C}$ with Lactococcus lactis strains inoculated. $L$. lactis MS22333 (口), L. lactis MS22337 ( $\Delta$ ) and a mixed culture of L. lactis MS22333 and L. lactis MS22337 $(\diamond)$ were inoculated with $K$. pneumonieae $(\cdots \cdots)$ at $10: 1 \mathrm{CFU} \mathrm{mL}^{-1}$. Control samples without inoculation of L. lactis strains in past. camel milk $(-\times-)$ inoculated with $K$. pneumonieae (- - - -). 
Figure 1. Evolution of novel L. lactis strains and Gram-negative bacteria in raw camel milk.

399 Figure 1A. Growth curves of lactose fermenting strains on M17 agar with $0.5 \%$ lactose from raw camel milk fermentations at $30^{\circ} \mathrm{C}$ with Lactococcus lactis strains inoculated. L. lactis

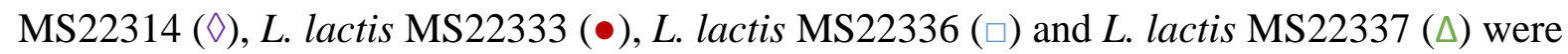
inoculated in raw camel milk with $E$. coli $O: 157 \mathrm{VT}^{-}(\cdots \cdots)$ at 10:1 $\mathrm{CFU} \mathrm{mL}^{-1}$. Control samples without inoculation of $L$. lactis strains in raw camel milk $(-\times-)$ or with E. coli $O: 157 \mathrm{VT}^{-}(\cdots \circ \cdots)$ inoculated.

Figure 1B. Growth curves of Gram-negative strains on MacConkey agar no. 3 from raw camel milk fermentations at $30^{\circ} \mathrm{C}$ with Lactococcus lactis strains inoculated. L. lactis MS22314 ( $\diamond)$, L. lactis MS22333 (•), L. lactis MS22336 ( $\square)$ and L. lactis MS22337 ( $\triangle$ ) were inoculated in raw camel milk with E. coli $O: 157 \mathrm{VT}^{-}(\cdots \cdots)$ at 10:1 CFU $\mathrm{mL}^{-1}$. Control samples without inoculation of L. lactis strains in raw camel milk $(-\times-)$ or with E. coli $0: 157 \mathrm{VT}^{-}(\cdots \circ \cdots)$ inoculated.

Figure 2. Evolution of novel L. lactis strains and pathogenic bacteria in pasteurised camel milk.

Figure 2A. Growth curves of Lactococcus lactis strains in pasteurised camel milk with Salmonella Typhimurium DT12 or Klebsiella pneumoniae present. L. lactis MS22333 ( $\square$ ), L. lactis MS22337 ( $\triangle)$, a mixed culture of L. lactis MS22333 and L. lactis MS22337( $\diamond)$ were inoculated with either $S$. Typhimurium DT12 (- - ) or K. pneumonieae (.....) at 10:1 CFU $\mathrm{mL}^{-1}$. Control samples without inoculation of $L$. lactis strains in past. camel milk $(-\mathrm{X}-)$ inoculated with either $S$. Typhimurium DT12 (- - - -) or K. pneumoniae $(\cdots \circ \cdots)$.

Figure 2B. Growth curves of Salmonella Typhimurium DT12 on XLD agar from pasteurised camel milk fermentations at $30^{\circ} \mathrm{C}$ with Lactococcus lactis strains inoculated. L. lactis MS22333 ( $\square)$, L. lactis MS22337 $(\triangle)$ and a mixed culture of L. lactis MS22333 and L. lactis MS22337 ( $\diamond)$ were inoculated with $S$. Typhimurium DT12 (- - ) at 10:1 CFU mL ${ }^{-1}$. Control samples without inoculation of L. lactis strains in past. camel milk $(-\times-)$ inoculated with $S$. Typhimurium DT12 (- - - - ).

Figure 2C. Growth curves of Klebsiella pneumoniae on MacConkey agar no. 3 from pasteurised camel milk fermentations at $30^{\circ} \mathrm{C}$ with Lactococcus lactis strains inoculated. $L$. lactis MS22333 (口), L. lactis MS22337 $(\triangle)$ and a mixed culture of L. lactis MS22333 and L. lactis MS22337 $(\diamond)$ were inoculated with $K$. pneumonieae $(\cdots \cdots)$ at $10: 1 \mathrm{CFU} \mathrm{mL} \mathrm{m}^{-1}$. Control samples without inoculation of $L$. lactis strains in past. camel milk $(-\times-)$ inoculated with $K$. pneumonieae (- - - =-). 
Table 1. $\mathrm{H}_{2} \mathrm{O}_{2}$ levels in raw and pasteurised camel and bovine milk fermented with L. lactis strains MS22333 or MS22337 at $30^{\circ} \mathrm{C}$

\begin{tabular}{llll}
\hline \multicolumn{1}{c}{ Sample } & \multicolumn{3}{c}{$\mathbf{H}_{2} \mathbf{O}_{2}$ (ppm) } \\
& $\mathbf{0 ~ h}$ & $\mathbf{3 ~ h}$ & $\mathbf{2 4} \mathbf{~ h}$ \\
\hline Raw camel milk (RC) & $<\mathrm{DL}$ & $\mathrm{X}^{*}$ & $\mathrm{X}^{*}$ \\
Raw Bovine milk (RB) & $<\mathrm{DL}$ & $\mathrm{X}^{*}$ & $\mathrm{X}^{*}$ \\
Pasteurised camel milk (PC) & $<\mathrm{DL}$ & <DL & 4.2 \\
Pasteurised bovine milk (PB) & $<\mathrm{DL}$ & $<\mathrm{DL}$ & 4.1 \\
RB_MS22333 & 2.9 & $<\mathrm{DL}$ & 15.0 \\
RC_MS22333 & 1.5 & $<\mathrm{DL}$ & 3.6 \\
RB_MS22337 & $<\mathrm{DL}$ & $<\mathrm{DL}$ & 14.2 \\
RC_MS22337 & $<\mathrm{DL}$ & $<\mathrm{DL}$ & 4.3 \\
PB_MS22333 & <DL & <DL & 17.3 \\
PC_MS22333 & <DL & <DL & 7.4 \\
PB_MS22337 & <DL & <DL & 6.6 \\
PC_MS22337 & <DL & <DL & 23.8 \\
\hline
\end{tabular}

${ }^{*} \mathrm{RC}$ and $\mathrm{RB}$ were only measured at $\mathrm{t}=0 \mathrm{~h}$ for baseline.

$D L$ refers to below detection limit which is $1.5 \mathrm{ppm}$ 


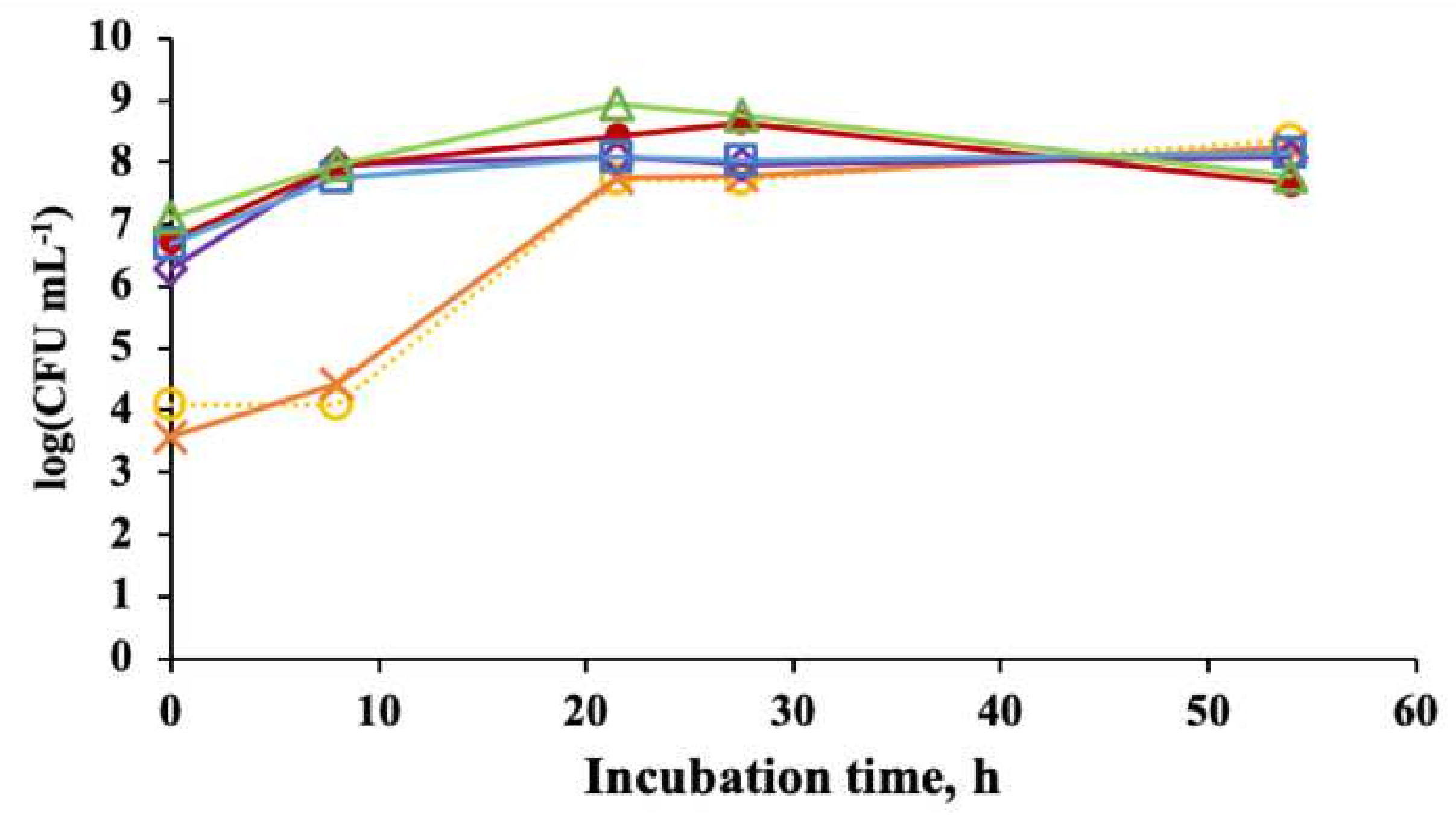




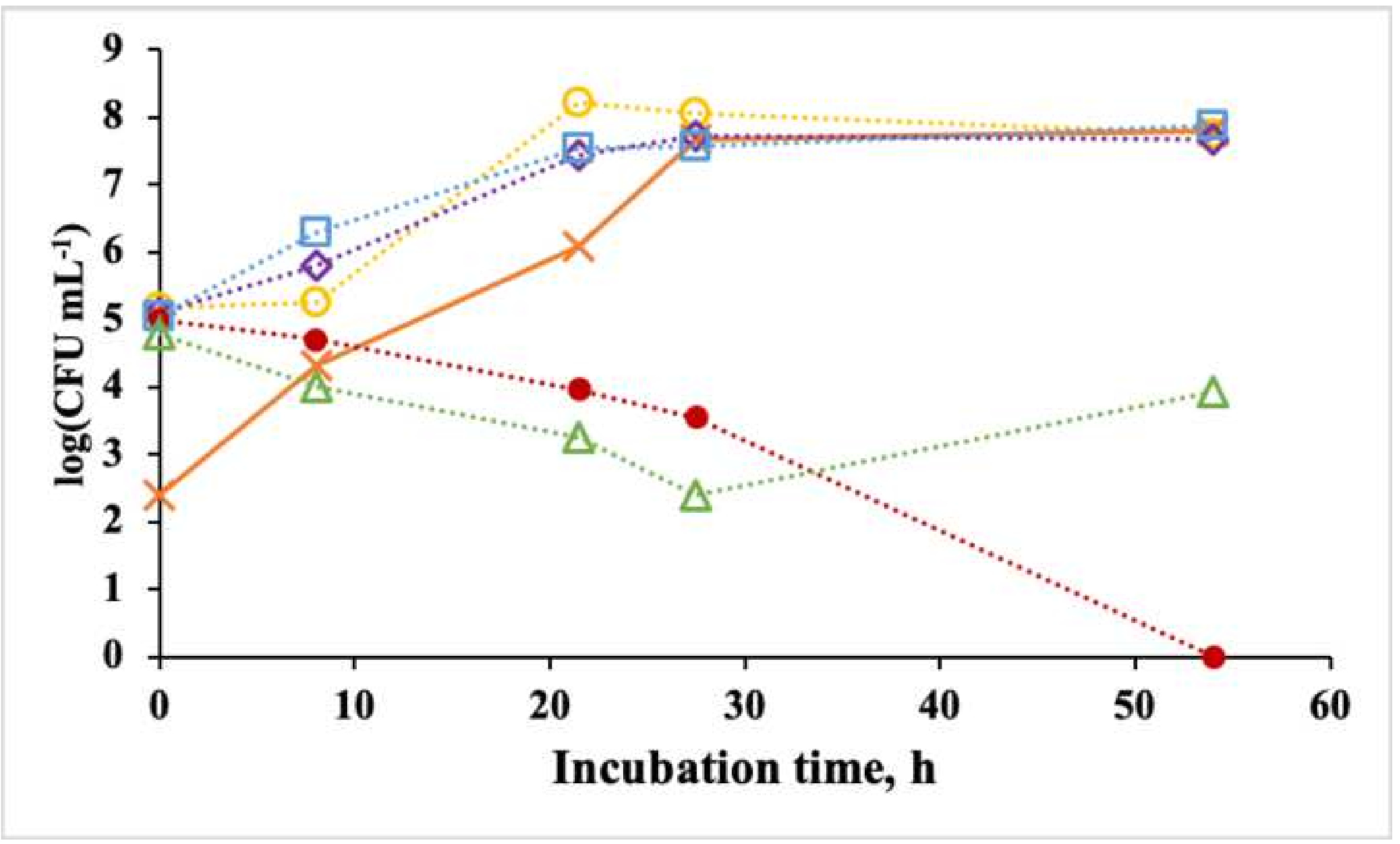




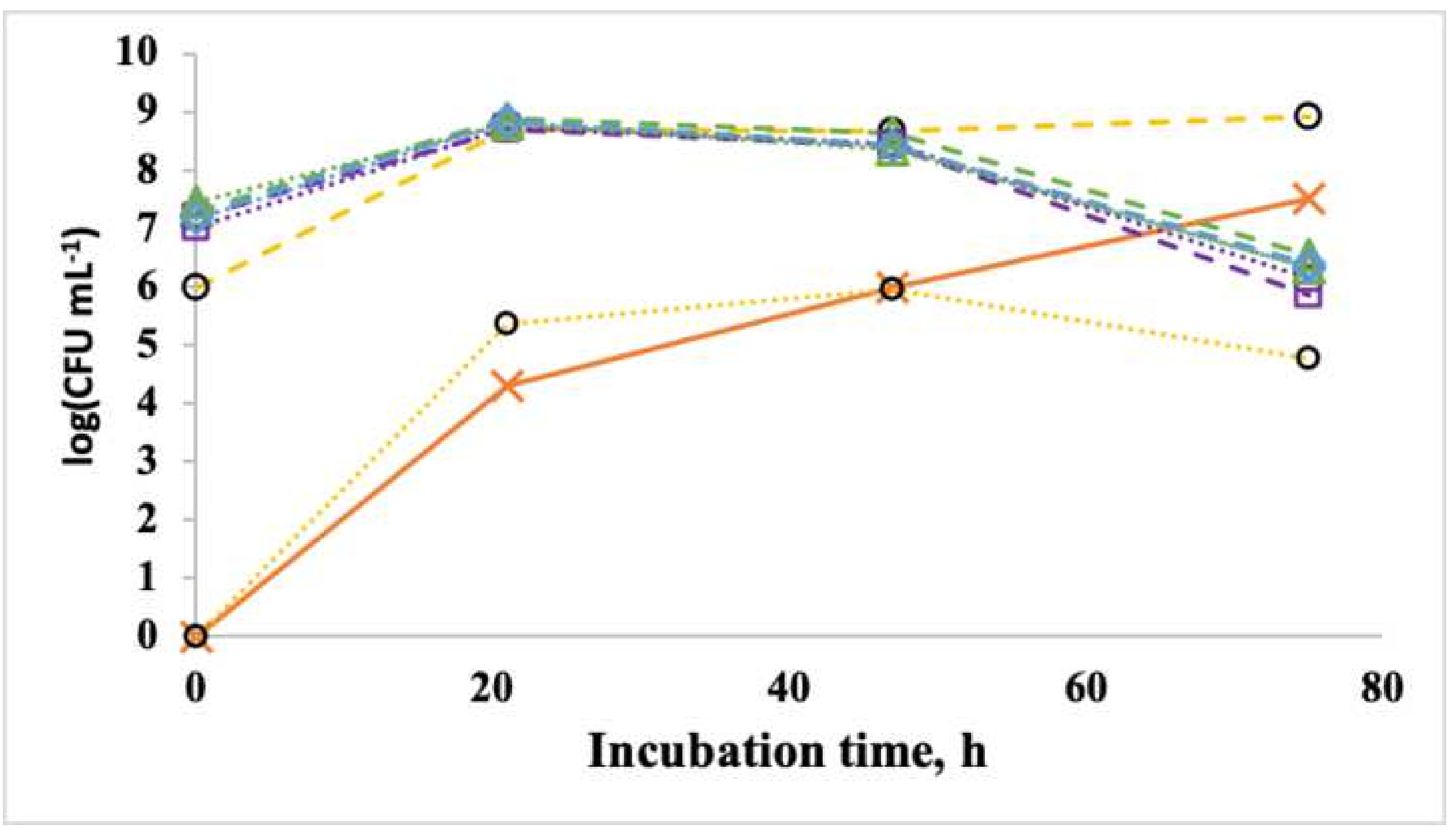




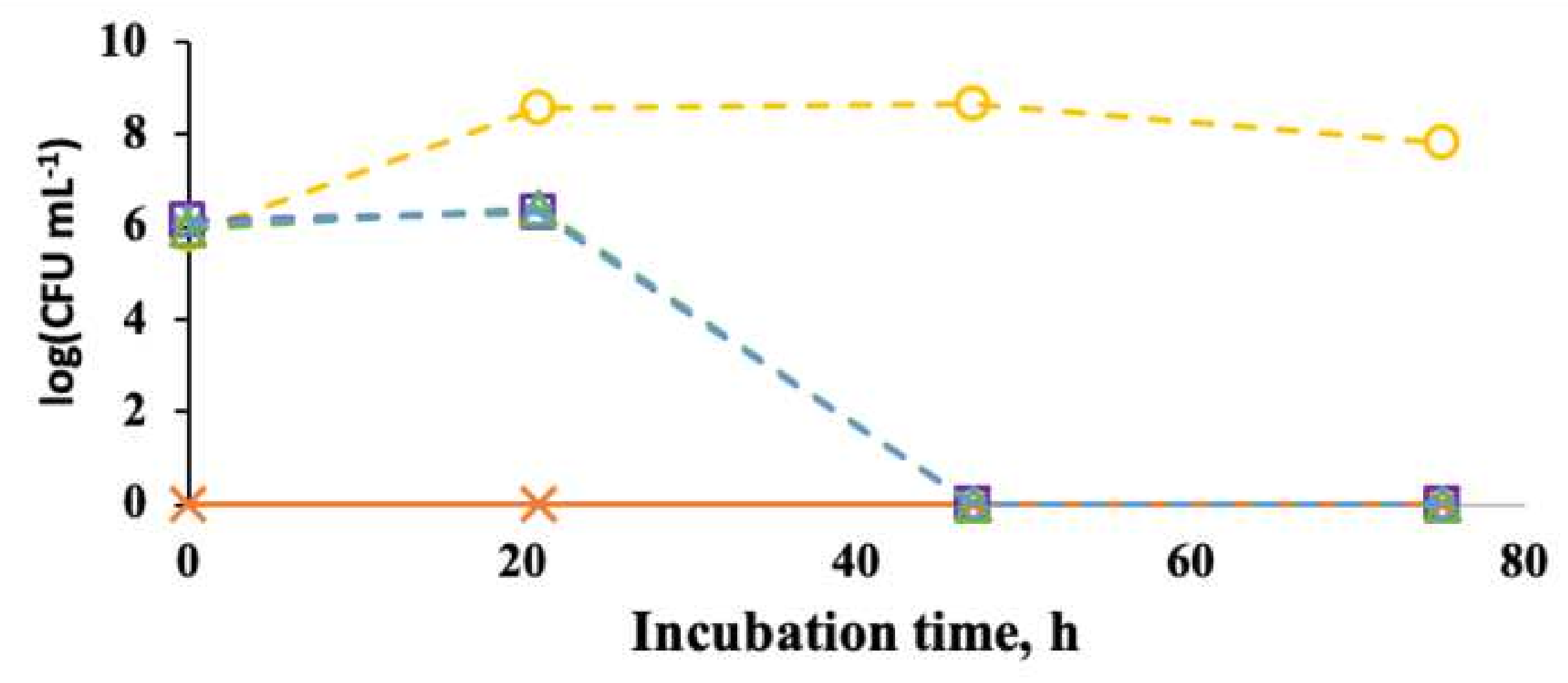




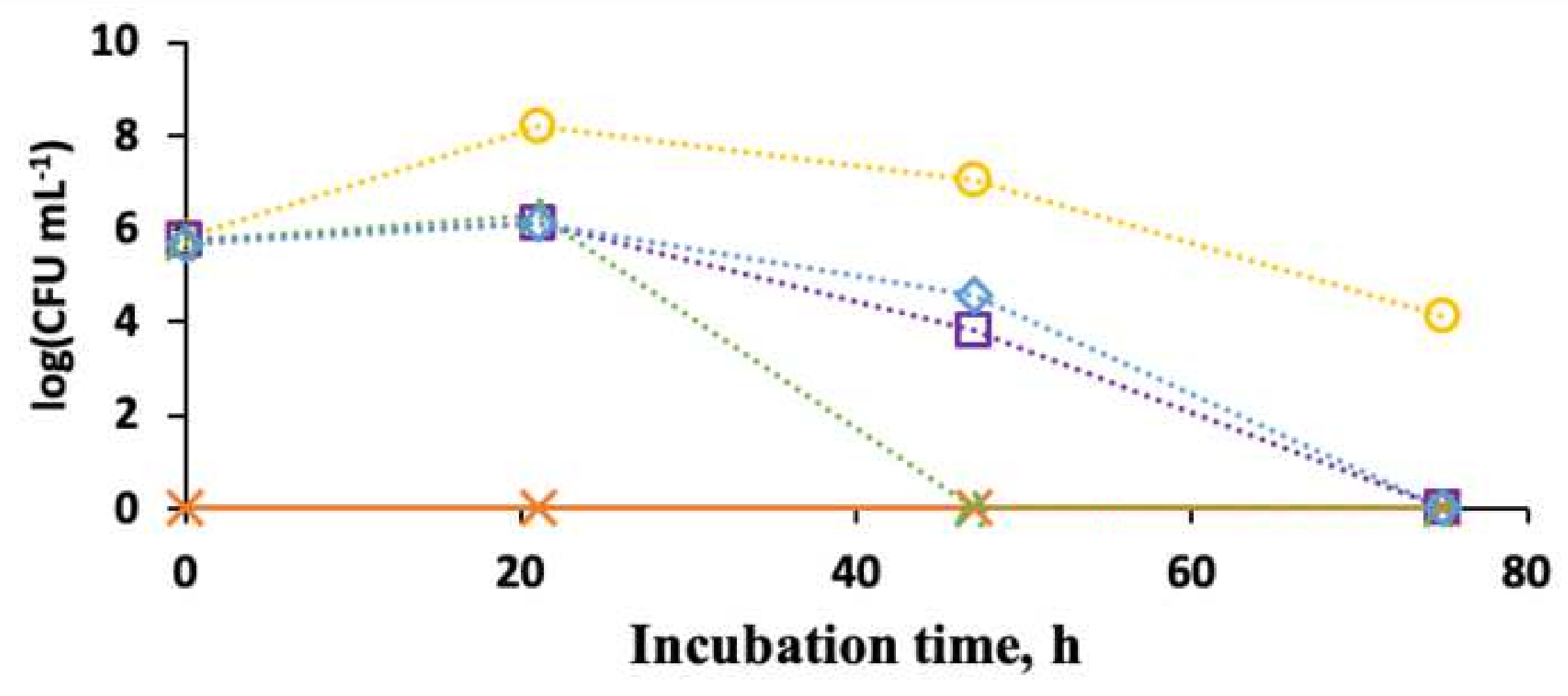


$$
\text { Credit Author Statement }
$$

Esben Bragason: Conceptualization, Investigation, Writing; Tesfemariam Berhe: Resources;

DakaloDashe: Resources; Kim Ib Sørensen: Validation; Mituku E. Guya: Resources; Egon

Bech Hansen: Supervision, Funding acquisition. 